\title{
The Economic and Sharia Value of Moslem's Awareness for Halal Food in Indonesia
}

\author{
Indah Susilowati ${ }^{1}$, Edy Riyanto ${ }^{2}$, Mayanggita Kirana ${ }^{3}$, Izza Mafruhah ${ }^{4}$,Alias \\ Radam $^{5}$
}

${ }^{1,2,3}$ Faculty of Economics and Business, Diponegoro University, Semarang 50275, Indonesia. Jl Erlangga Tengah 17 Semarang 50241. Tel/ Fax: +62-24-8442273

${ }^{4}$ Faculty of Economics and Business, Sebelas Maret University, Surakarta, Indonesia, Jl Ir Sutami no 36 Jebres Surakarta, Tel/Fax +6271647481

${ }^{5}$ Faculty of Economics and Management. Universiti Putra Malaysia. 4300 Selangor Darul Ehsan Malaysia

*Corresponding Author: indah-susilowati@rocketmail.com; indahsusilowati@undip.ac.id

Recieved March 2018 | Revised: March 2018 | Accepted May 2018

\begin{abstract}
This study is aimed to explore an economic and sharia values of moslem awareness in Indonesia with a pilot project in Semarang City. The standard of halal used are defined from the points of: (1) input or material come from; (2) how to get the input; (3) how to process the input; (4) how to store the input; (5) how to transportage the input; and (6) how to package and serve the input. This study uses sequential mixed method, which is a combination of quantitative and qualitative methods to analyse the data. The results indicated that the level of awarness for consuming the halal food are vary among the moslem community by her/ his income- and sharia-stratum as perceived by them. It is hardly difficult to aware people of A-B-G-C accordingly for halal food in such high intense of diversity in community in short-term. Of course, a lot of efforts and strong committment among the stakeholders is indeed needed to ensure the halal food consumed by moslem in Indonesia.
\end{abstract}

Keywords: halal, food, value, sharia, economic, Indonesia.

JEL Classification: L66, A11

How to Cite: Susilowati, I., Edy Riyanto, E., Kirana, M., Mafruhah, I., \& Radam, A. (2018). The Economic and Sharia Value of Moslem's Awareness for Halal Food in Indonesia. Jurnal Ekonomi Pembangunan: Kajian Masalah Ekonomi dan Pembangunan, 19(1), 102-113. doi:https://doi. org/10.23917/jep.v19i1.5859

DOI: https://doi.org/10.23917/jep.v19i1.5859

\section{Introduction}

The concept of halal food during this onedecade has a strategic position. Consumer spiritual understanding of the importance of halal food as a food in accordance with sharia law that is maintained cleanliness, quality and security of its products, has opened up opportunities for new market developments. Certainty of halal food products not only on the final product but includes raw materials and production processes. To maintain consumer confidence in the halalness of the product, the government establishes a guarantee's certification institution. Indonesia as a country with the largest Muslim population in the world becomes a very big market for halal food products, therefore this research is conducted to encourage businessmen to develop halal food products not only as an economic problem but 
also to maintain consumer confidence.

Halal foods are permissible foods by Islamic rules and Muslims are obligated to consume them. The concept of halal foods remains unheard in non-Muslim countries until recently. With the increase in awareness among them, the previously distinct element of Muslims is now becoming international matter. Halal food has become an attractive industry to firms due to its huge target market valued at US $\$ 661.6$ billion as at 2015 (Shikoh, 2015). Halal, which means "permissible" or "allowed" in Arabic, is essentially a way of life and is not solely confined to the types of food that a Muslim is allowed to consume, though food is a vital component for the sustenance needed to lead a meaningful life. The bottom line is that Halal food is not just about what the food is but how it is prepared. The Halal concept emphasizes safety, hygiene and wholesomeness of food. It also provides an excellent platform for healthy eating. Consideration of the place and process of the animals being slaughtered and most importantly, the condition of these animals would not endanger the health of diners, are a prime focus of what Halal is all about. Today, Halal is no longer a mere religious obligation or observance, but is considered as the standard of choice for Muslims as well as non-Muslims worldwide (Wahab, 2004) Drinks and Goods Utilized by Muslim' published by Bahagian Hal Ehwal Islam, Jabatan Agama Islam (Jabatan Kemajuan Islam Malaysia -JAKIM.

Practices and prescribes practical guidelines for the food industry on the preparation and handling of Halal food (including nutrient supplements) based on quality, sanitary and safety considerations and serves as a basic requirement for food products and food trade or business in Indonesia. Halal has now become a universal concept. Halal stands not only for just and fair business but also for animal welfare, social justice and sustainable environment. It is no longer a concept confined or restricted to the slaughtering of animals for the consumption of Muslims but encompasses products and services of the highest quality that meet the ever increasing awareness and needs of non Muslim consumers in a demanding market (Elasrag, 2016).

Indonesia is a multi-ethnic, multicultural and multilingual society. There is a lack of participation among Small Medium Entrepreneurships (SMEs) establishments to get Halal certification. It is due to the assumptions made by the consumers to believe that since the SME operators or owners are Muslims, the products produced must be Halal. In Indonesia nevertheless, the participation of Indonesian companies in this sector is still very low compared to other global players despite her facing an increasing challenges in their domestic market (Anggara, 2017). Halal sector now holds the key to a greater global market, thus it is becoming inevitable for Indonesian food companies to consider it as a strategic vector for repositioning the efforts of penetrating this new market. The government and private sector have conducted training, counseling and mentoring to SMEs, but they will lose if they fail to comply with the requirements and food security standarts. Rapid growth of the halal industry encourages businesses to seek halal certification for their products. Halal certificates and logos are indispensable in gaining global market share and to retain consumers. Products that have Halal certification provide assurance to the consumers particularly the Muslims that the ingredients used and the production processes are according to shariah. Nevertheless, much left to be explored on the issue of whether the Halal logo itself is sufficient and sole contributor for consumers in purchasing decision .

Issue quality and food safety at the international and national levels has attracted a lot of attention among the government, experts, NGOs and consumers in various countries around the world including Indonesia. Therefore, quality and food safety has become a way of life (life-style) for a modern society. But in Indonesia awareness to consume food that is healthy, nutritious and safe, are already beginning to be felt and a growing 
concern along with the demands of the halal food (Abdul Manaf, Cheng, \& Nurwahida, 2013). Most of these Halal food products are produced by non-Muslims countries rather than produced by Muslim countries. For example, it is a true and interesting fact that almost all Halal meat exporters in the world come from non-Muslims countries such as Argentina, Australia, Brazil, Canada, France and New Zealand (Melissa \& Hassan, 2015). Muslim communities around the world are well aware that Halal industry and Islamic matters in these countries are not under the direct jurisdiction of the federal and state government. Therefore, the authenticity and integrity of the Halal food products that came from these non-Muslims countries is questionable.

Therefore, it is important to create the proper awareness and better understanding among the parties involved in the Halal food supply chain on the importance of protecting the Halal integrity of the food products. Failure to address this will lead to dissatisfaction of the Halal food consumers and unnecessary wastage of non-consumable Halal food products. Institute for Assessment of Food and Cosmetics Cosmetics of Indonesia Ulama Council (LPPOM MUI) of Central Java stated that the awareness of Central Java entrepreneurs to seek halal certification on their products is still low. Data of 2018 shows only 10\% of SME Central Java that already has halal certification (http://jateng.tribunnews.com/2018/01/15), thus the main objectives of this paper are to explore an economic values of muslim awareness in Central Java and to provide a conceptual framework in enhancing the integrity of the Halal food supply chain.

\section{Materials And Methods}

The word "Halal" means permissible or lawful by Islamic laws. It refers to foods or products consumed by Muslim. Halal when used in relation to food in any form whatsoever in the course of trade or business or as part of a trade description, is applied to lawful products or foods or drinks. Halal can also take any other expression indicating or likely to be understood as permission by Islamic religion to consume certain things or utilize them (Wahab, 2004) Drinks and Goods Utilized by Muslim' published by Bahagian Hal Ehwal Islam, Jabatan Agama Islam (Jabatan Kemajuan Islam Malaysia -JAKIM. Such expression shall have an indication that neither is such thing consists of or contains any part or matter of an animal that a Muslim is prohibited by Shariah to consume. In addition, if it is an animal, it would indicate that it has been slaughtered in accordance with Hukum Shariah. In other words, it does not contain anything which is considered to be impure according to Hukum Shariah. If it is food stuffs, it means that it has not been prepared, processed or manufactured using instruments or ingredients that were not free from anything impure according to Hukum Shariah. Moreover, it and has not in the course of preparation, processing or storage been in contact with or close proximity to any things that are considered to be impure according to Shariah law. Thus, in Islam, all foods are considered halal except the following, which are Haram: swine/ pork and its by-products; animals improperly slaughtered or dead before slaughtering; animals killed in the name of anyone other than ALLAH (God) and drinks such as alcohol and intoxicants. Haram also covered carnivorous animals, birds of prey and land animals without external ears; blood and blood by-products and foods contaminated with any of the above mentioned products as they are raised to eat or drink halal, hygienic and safe foods or products (Salman \& Siddiqui, 2011).

Most, but not all, religious diets prescribe a variety of foods on a temporal or permanent basis, and thus these diets become restrictive in nature. A survey conducted by Bergeaud-Blackler (2004) shows that the Halal meat products are chosen by French Muslims not because of religious obligation, but consumers also believe that 
Halal products were tastier, healthier and the Islamic slaughter method is less painful for the animal. Fundamental problems that arise are the different definitions of Halal food and the different perceptions among non-Muslim consumers. The Halal food chain is therefore adapting to newly emerging consumer interests like food safety, animal welfare and convenience in cooking and eating (Bergeaud-Blackler, 2004). According to Cutler (2007), most consumers believe that Halal and Kosher food products follow stricter safety and quality standards than non-Halal and nonKosher products in the same category. Given the extra food safety and rigor in standards in the production of Halal and Kosher foods and with consumers responding to such food production practices, food manufacturers are considering the efficacy of expanding their marketing reach far beyond the religious rationale as profitability rests in foods designated as Halal and Kosher (Cutler, 2007).

Hygiene has been given much emphasis in halal and it includes the various aspects of personal body, clothing, equipment and the working premises for processing or manufacture of foods, drinks and products. The objective is to ascertain that the food (whatever kinds) produced is safe, hygienic and not hazardous to human health. In the context of halal, hygienic food, drinks and products can be defined as free from najis or contamination and harmful germs. So, it obviously shows that halal is very particular in food matters especially in the practice of keeping ourselves and the things around us clean in order to prevent diseases. Hence a safe food, drink or product is one that does not cause harm to the consumers be Muslim or non-Muslim when it is prepared and/or eaten or in accordance to its intended usage. In order to assure we are safe the producers should take necessary steps to comply with Good Manufacturing Practice (GMP) and Good Hygiene Practice (GHP). Good Manufacturing Practice is where the producers apply the combination of manufacturing and quality control procedures to ensure the products are consistently manufactured to their specifications and halal prescriptions given by Halal Certification Body (Wilson \& Liu, 2010).

While according to Randolph (2003), the word "awareness" means the knowledge or understanding of particular subject or situation. The word "awareness' in the context of halal literally means having special interest in or experience of something and/or being well informed of what is happening at the present time on halal foods, drinks and products. As such, awareness describes human perception and cognitive reaction to a condition of what they eat, drink and use. Subjectively speaking, awareness is a relative concept where a person may be partially aware, subconsciously aware or may be acute aware of an issues relating to halal aspect of what is permitted by Allah. It may be focused on an internal state, such as a visceral feeling or on external events or issues by way of sensory perception. Awareness provides the raw material to develop subjective ideas about one's experience related to something (Abdullah, 2006). Awareness about something is therefore a basic part of human existence. On top of everything is the self-awareness. Awareness means one exists as an individual with private thoughts about the state of something. Therefore, different people have different level of awareness about something. In other words, awareness is the processes of informing the general population or increasing levels of consciousness about risks related to anything that could endanger human life and how people can act to reduce their exposure to it. So, awareness in the context of halal can be conceptualized as the informing process to increasing the levels of consciousness toward what is permitted for Muslims to eat, drink and use.

Halal food supply chain involved the process of managing Halal food products from different points of suppliers to different points of buyers/ consumers, which involved various different parties, who are located at different places, who 
may at the same time, involved with managing non-Halal food products, with the purpose of satisfying the needs and requirements of both (Halal and non-Halal) customers. In Halal food supply chain, the main goal is not only to ensure that satisfaction of the customer is achieved, but also to ensure that the Halal status of the food product remains intact throughout the whole process of the supply chain (Bahrudin, Illyas \& Desa 2011). The food products must not only be Halal at the supply chain starting point but throughout the supply chain until it reaches its final destination. The possibility of becoming nonHalal is greater when the food product needs to travel a greater distance whereby a lot of handling points will be involved. These handling points can be the critical control points of which the Halal status of the food products can be breached if the concept of Halal integrity is not fully understood by all parties involved in the supply chain especially those who are involved directly in the operational handling aspect.

As this study addresses the issue of a wareness towards halal consumption the unit of analysis is individual Muslims The first technique is known as judgmental sampling, which allowed the study to identify homogeneous samples within the population. The other sampling technique used is the snowball sampling that guided the study to locate other samples that might exhibit the same characteristics. Samples are classified according to occupation and position. As stated in the introduction, that halal food is not only the final product, but also the raw materials and production process so that the sample selection is classified as farmers and meat producers, representing raw material providers, traders representing the production process and consumers as end-product users.

In terms of sample size, 200 Muslims were chosen as the respondents. A convenience sampling was used to obtain information from a particular subset of Muslims. Therefore, a quota of 60 farmers (growers and feed millers), 30 traders,
20 meat producer and 60 consumers participated in this study. Secondary data were obtained from the slaughterhouses in every research areas. Thus, data was collected through personally administered questionnaires by research assistants. This method is chosen because the designed questionnaires could be collected from the informants within a short period of time and any doubts that the respondents might have about any item of the questionnaire can be clarified on the spot (Sekaran, 2010). Data for this study were collected using survey questionnaires that consisted of few closed ended as well as scaled questions. Therefore, the research was a crosssectional survey with mixed method approach.

The method used here is a sequential mixed method, ie a combination of quantitative and qualitative (Creswell, 2014). Quantitative analysis consists of descriptive statistics used to analyze profiles and characteristics of respondents. The results of quantitative analysis are discussed more comprehensively with qualitative analysis using phenomenology method. The tool used is indepth interview and focus group discussion. Qualitative analysis is used as an enrichment of results. The indepth interview approach provided the survey team with an opportunity to gather required information from several market chain actors and performances. FGDs are conducted using key persons consisting of government, academic, business actors and the communities.

The scope of this study is from "farm to table" for the selected three types of food commodities. In other words, the study investigates complete supply chain, in which, main players are classified into eight categories e.g. feed millers, growers, slaughterhouses, producers, storages, transporters, wholesalers and retailers as depicted in Figure 1. Based on the preliminary interviews and literature review, the eight categories of players are identified to be the most important players in the chain and are highly involved with the supply chain activities as well as implementation of halal practices. 


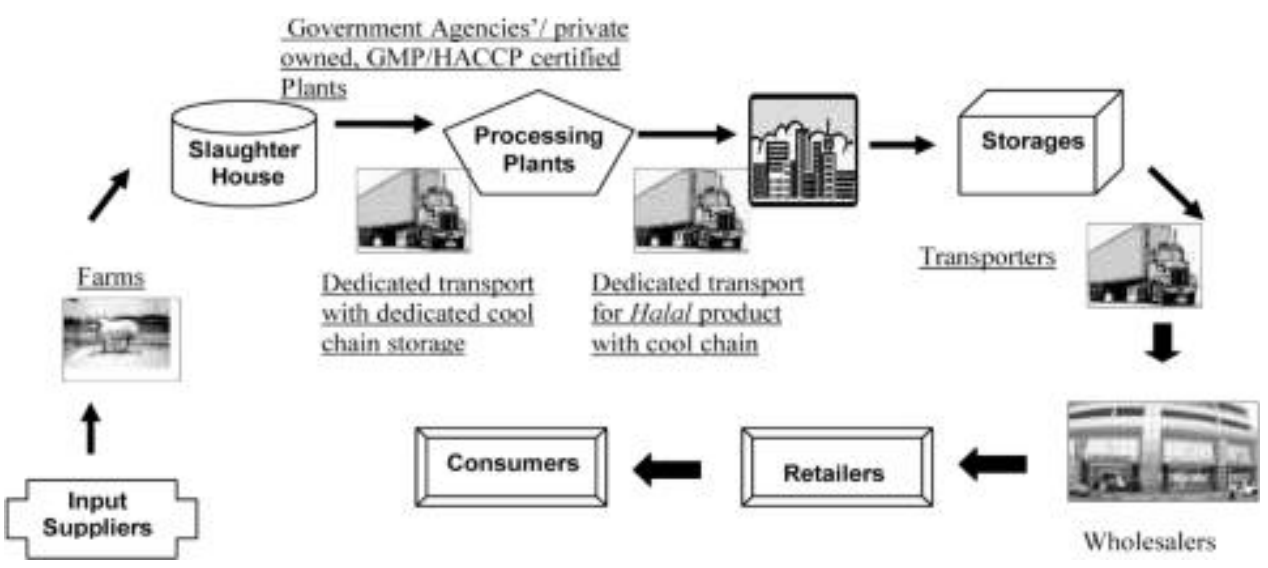

Figure 1: The Farm to Table Halal SCM Concept

Independent -

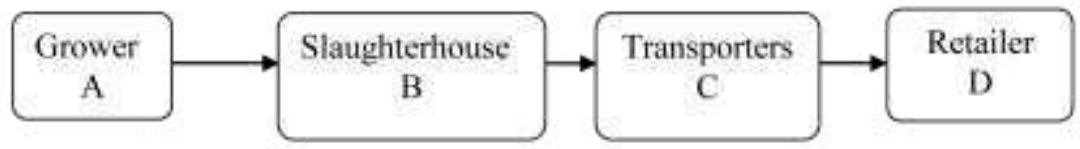

Small Integrator -

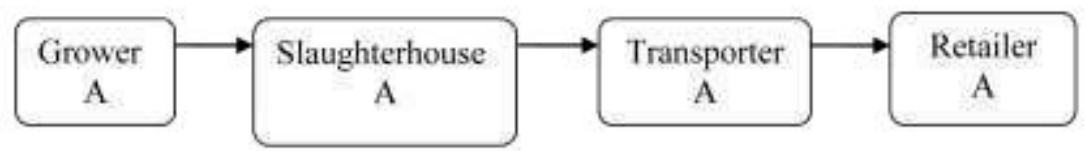

Big Integrator -

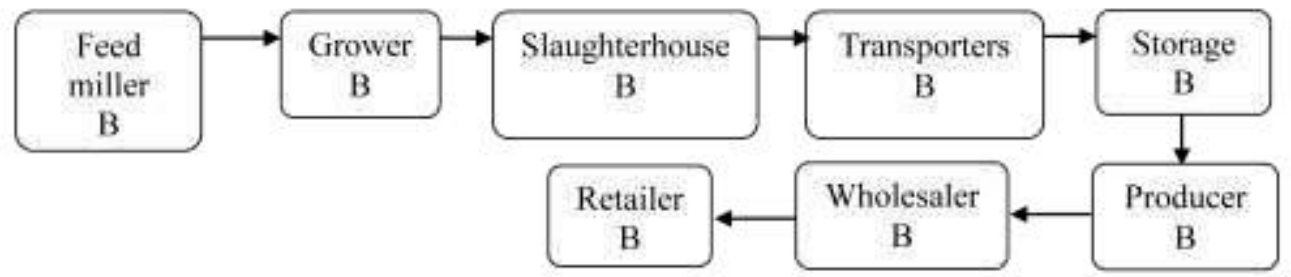

Figure 2: Structures of Halal SCM According to the Type of Company

\section{Results And Discussion}

\subsection{Supply Chain Analysis}

The total food industry sector in Central Java is 1058 which consists of large, medium and small businesses, the study of secondary data found that the market structure consisted of big integrator companies (30\%), whereas small integrators as well as independent farmers made up the remaining (70\%) (BPS 2017). Independent farmers posed the most challenging task in tracing the existence of halal SCM because most of these farmers were involved in small scale activities and did not have the financial capabilities to establish their own halal SCM as compared to the much bigger commercial farms. The study found that each structure has its own way of establishing the 
halal SCM with the big integrators having the clearest and well organised chains. The structures for each type of companies are given in Figure 2.

The supply chains depicted in Figure 2 indicate that as independent farmers, the study found these companies do not necessarily link to or depend on a particular contact along the supply chain. They are not restricted to a specific list of chain members and are free to source any companies that they feel provide them with the best deal. However, it was also found that not all contacts involved and contracted by the independent farmers are halal certified. As such, it is difficult to ensure that the supply chains implemented by these companies are totally halal, as dictated by LPPOM-MUI. These companies also have to source many critical services such as the feeds given to the animal. Due to their lack of resources, some of them failed to ensure that the ingredients used for the feed are halal. Many of them admitted that their main concern is the cost and to some extent, the extra services provided by the producers such as variety of packages, availability of the stocks and transporting the packages to their farms.

Another major concern related to the halal practices of the independent growers are the slaughtering activities. Although many of them claimed that they are either involved in live animal transactions or send the animal to the government slaughterhouses if the need arises, a few of them admitted that they are also willing to slaughter the animal themselves at the farm if requested by buyers. Some of these practices posed greater risks of tainting the halal status due to the lack of proper monitoring of halal food requirements. In fact, some independent growers that admitted to slaughtering the animal themselves did not have suitable facilities and equipment to perform the tasks.

Finally, another issue related to the supply chain practices of independent growers is the transportation aspect. Due to their small size, independent growers do not have their own fleet of refrigerated transport to service the industry.
They either rely on transport companies or perform the tasks themselves. However, as the transport companies may not have a dedicated fleet to service halal food industry, the cleanliness of the refrigerated trucks is questionable. In fact, there are also cases where the same refrigerated trucks were used to transport halal as well as non-halal food products at the same time. This mixing of halal and non-halal raise even more concerns about the halal practices of the supply chain structures of the independent growers. Those who perform the tasks themselves also admitted that they are facing storage limitation when transporting the meat and to a certain extent, affecting the quality of the meat as well. Thus, due to the constraints faced by independent growers, the establishment of halal supply chain becomes more challenging, particularly when the existing supply chain cannot be converted easily to cater for halal food.

The small integrators on the other hand, demonstrated some forms of integration along their supply chain structures although not completely integrated to their operations. In some cases, the small integrated companies are also contract farmers for the fully integrated corporate companies. Integrated companies, whether they are fully or small and partially integrated, do have advantage over their independent counterparts. For a start, these companies usually have the necessary resources to set up their own supply chain structures that are dedicated to serve the halal food industry. They have their own fleet of dedicated refrigerated transport that service the whole chain and this has taken away the risks of cross contamination during transportation activities. Furthermore, they also have their own slaughtering facilities that are certified and monitored by LPPOM-MUI to conduct all the slaughtering activities. These facilities are also manned by qualified workers that have been well trained. Most importantly, they also ensure that all players that have been integrated into their supply chain are certified by LPPOM-MUI to maintain proper monitoring system of the halal 
practices implemented by these players. As a result, integrated companies appeared to have a better, more organised and properly certified halal supply chain. Therefore, even though Central Java-Indonesia still has not established a comprehensive and dedicated halal supply chain for the industry, upgrading the existing integrated supply chain structure might just be the right solution for the halal food industry.

The results of research on primary data show, 62 percent of the feed millers and growers used imported raw materials instead of using local raw materials (38 percent). The type of animal, plant and synthetic based feed account for 11 percent. In relation to the feed millers that produce the animal feed, most of them (50 percent) said that they are well aware of the halal requirements for the preparation of the animal feed. Only a handful (6 percent) mentioned that they are not aware about any halal requirements that they have to abide by as they are only producing animal feed and are not involved with the production of halal food. They are also unaware of the concept of halal that stresses on practices from the farm to the table. As far as they are concerned, animal feed does not necessarily need to be certified as halal and as far as their practices go, they have not breached any regulations on the production of animal feed.

The study is able to identify the halal practices implemented by the slaughterhouses in terms of halal standard (checklist from MUI); specifically on the aspects of workers, cleanliness of animals, surrounding area, types of input handled, sanitation and sewerage system, cleanliness of farms and storages, transportation. The number of halal and non-halal carcasses must be recorded at this point and be available for audit by LPPOMMUI. Carcasses that are not halal must be stamped as nonhalal and the stamping done under the supervision of the Muslim checker. Non-halal offal must not enter the same offal room as halal offal unless complete segregation of product can be achieved and is documented. Halal carcasses must be stored in separate chillers to non-halal carcasses or under controlled physical segregation.
Halal carcasses must be boned and packed prior to any non-halal product entering the boning room. Halal product must be stored separately from non-halal product under controlled physical segregation. The number of halal and non-halal cartons moving into and out of the cold store must be recorded. There must be regular reconciliation of the production records to verify the eligibility of halal products. These records must be available for audit.

Some producers label meat products as halal when these products are in fact not halal. It is possible that they will innocently believe that they are following the "rules" to label the meat as halal.

It is also possible that there is little concern other than marketing and sales driving these decisions. When a meat product is labeled as halal with no reference to the certifying organisation, the chances are high that the meat is mislabeled. A producer looking for halal meat as an ingredient must not assume that a meat item labeled as halal is indeed authentically halal. To be certain, request for a halal certificate for each lot of meat is a necessity. Since meat is the most critical ingredient, the supervising organisation must evaluate the supplier or recommend another supplier. Any producers wanting to buy halal meat as an ingredient must exercise extra care. For this study, it is indicated that most of the producers are producing or processing meats (64\%) into processed food.

\subsubsection{Attributes of Respondent's Buying Preference}

The responses are summarised in Table 1. The attribute, with 1 being the most important and being the least important, indicates the respondents' buying preference when selecting halal meat products. Five attributes were used to investigate the Muslim consumers' buying preference when selecting halal meat products before making a purchase decision. It showed that $62 \%$ of the consumers ranked "Display of halal logo and certificate" as top priority in making their decisions to purchase halal meat products followed 
by the "observation of $100 \%$ halal supply chain and logistics from farm to retailers". These figures were considered noteworthy and raised some concern about current infrastructure of supply chain for halal meat products. Majority of the consumers believed that the presence of halal mark from a recognised organisation on the packaging by display their halal logo and certification is extremely important attribute (average mean score is 4.82). The display of halal logo will give consumers, the confidence to purchase the halal meat products because companies involved in halal business are mainly the non-Muslims.

In addition, respondents highlighted that it is very important that halal meat products be handled by trained employees and/or workers (average mean score is 4.41). These scores do not fall into the 'extremely important' range. Respondents also stressed that it is extremely important for Halal meat be stored inside a separate cold room of the store and/or supermarket (average mean score is 4.58). However, these two attributes need the full commitment from the companies and businesses in order to constantly upgrading and monitoring of the halal integrity. Many respondents stressed that training is crucial to the success of Halal supply chain meat products. Respondents did not place any level of importance to the prices of Halal meat products before making a purchase or they were indifferent. The mean score of 3.41 for this criterion is the lowest among the other selection criteria. Respondents also indicated that it is extremely important that halal meat products not be placed near nonhalal meat such as pork in the same display space (average mean score is 4.51).
Many respondents were of the same opinion saying that monitoring is the key to ensure there is no possible contamination.

Consumers agreed that the production, processing and distribution of Halal meat products involve different companies at various production stages and service companies providing transport and packaging. As such, these consumers know that it would be a difficult task to upkeep the halal integrity of the whole supply chain as it requires constant monitoring. Consumers also strongly agreed that food must not contain anything in its preparation, processing, transportation, or storage using means or facilities that is unlawful according to Islamic law. They are agrred that Halal food rules must apply to the food production, storage, transportation, distribution, preparation and final consumption. Many respondents felt that Halal must be observed starting from slaughtering, transportation used to transport meat and place to store the meat. Some suggested that dedicated Muslims should be placed and oversee the whole process. In addition, respondents agreed that Halal and non Halal meat products must be kept separately throughout the supply chain to avoid the risk of contamination of the Halal products. Lastly, respondents strongly agreed that stringent hygiene and sanitation standards must be adhered to during processing of Halal food. Overall, the consumers believed that it is very important to meet and satisfy the Halal food requirements. This also shows that these respondents are aware of the requirements needed since Muslims have to consume Halal meat products which are halal and toyyib.

Table 1. Respondents' Buying Preference for Halal Meat Products

\begin{tabular}{lccccc}
\hline \multicolumn{1}{c}{ Attribute $(\mathbf{n = 6 0 )}$} & $\mathbf{1}$ & $\mathbf{2}$ & $\mathbf{3}$ & $\mathbf{4}$ & $\mathbf{5}$ \\
\hline Prices of Halal meat Products & 10 & 5 & 13 & 8 & 24 \\
Display of Halal Logo and Certificate & 36 & 9 & 5 & 3 & 7 \\
Separate cold storage/ refrigerator/ display space & 21 & 14 & 12 & 8 & 5 \\
Observation of 100\% Halal supply chains and logistics from farm to retailers & 26 & 9 & 10 & 8 & 7 \\
Cleanliness of the butcher/grocery/ supermarket & 25 & 8 & 10 & 11 & 6 \\
\hline
\end{tabular}




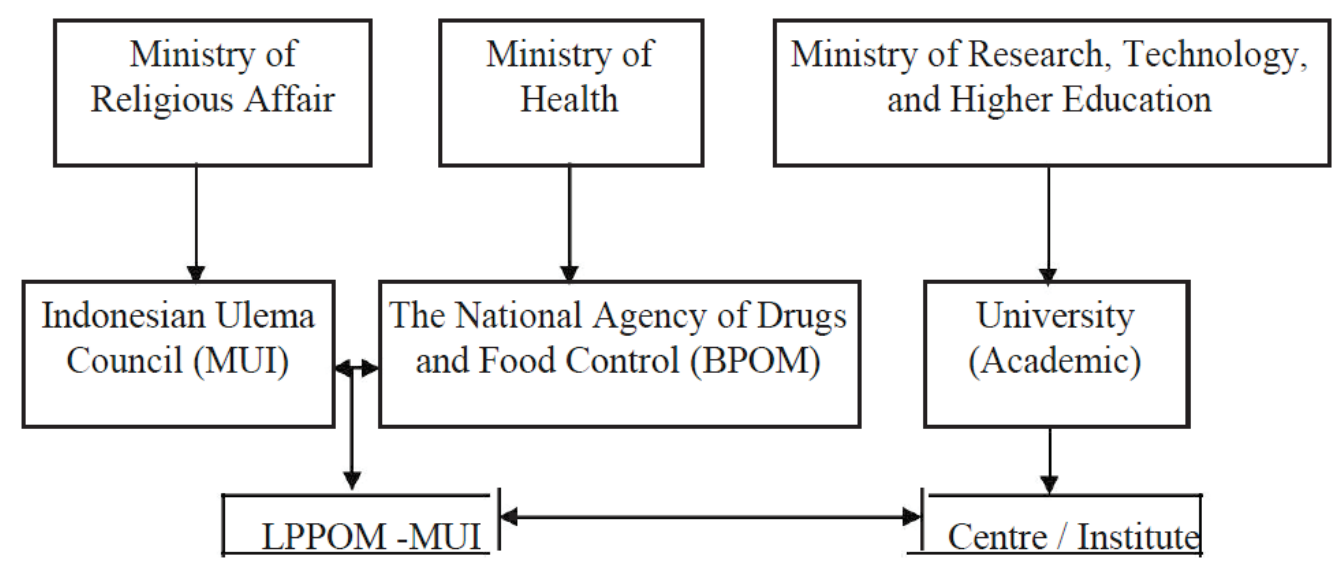

Figure 3. Tripatit design as an institutional arrangement of halal certification

\subsubsection{Strategy for Enhancement the Awareness}

Focus Group Discussion (FGD) with the representative of stakeholders as well as academicians was conducted to outline the strategy for establishing institutional arrangement for halal institutional design (called Tripatit Model) in Figure 3. The institution is exactly what can be expected to play an important role in analyzing and addressing cases of kosher food. In the process and implementation of halal certification, LPPOM MUI cooperates with a number of university/colleges in Indonesia. LPPOM MUI is the institution in charge of strong researching, reviewing, analyzing and deciding whether the products of good food and its derivatives, medicines and cosmetic products are safe for consumption both on health and the teaching of Islamic religion that is halal, or permissible and good to eat for the people Muslims especially in Indonesia, in addition to providing recommendations and guidance to formulate the provisions of the public service. Academicians through institute / centre are expected to provide provides halal-related training programs for participants who require knowledge on matters pertaining to the basic principles of halal, awareness on the needs of halal certification within the industry, procedures on the applications for halal certification, managing business related matters using halal-based administration and services, and knowledge on halal identification and audit that serves to benefit all of mankind.

Respons of respondents provided triangulation to the data gathering process by give their ideas/suggestions on how to improve the current supply chains and logistics for the halal meat products. Respondent suggested that the general public must be educated so that they are aware that halal certification does not mean 'no pork, no lard' but rather the overall handling of the meat product, from the farm to the store. Similar words such as 'make clear', 'educate nonMuslims', 'proper handling of halal product', 'avoid misunderstanding' were used. After qualitative analysis using in depth interview, then focus group discussion was conducted and the result of recommendation was made in the form of action plan as follows :

1. To develop halal vertical integration for better coordination from farm to table;

2. To establish and transform the halal marketing infrastructure especially for food products;

3. To promote halal farm training of the practices in the areas of feed mill, farm practices, transporting, striating, grading, packaging, labelling, sealing, producing and selling the food products;

4. To be the catalyst for the development of an efficient halal distribution, logistics and storages system for agro business to meet 
the specific requirements of a wide variety of market users, including farmers and farmers' organisations, cooperatives, packing houses, specialty and general retailers, hypermarkets, supermarkets, as well as secondary wholesalers;

5. To create an efficient halal market intelligence through an effective pricing mechanism that can ensure fair and transparent competition among suppliers and wholesalers;

6. To establish the partnership and alliances towards a halal distribution link, and to facilitate feedback of information on changing consumer preferences to the producers.

7. To encourage companies to devise their own Halal control points for the slaughtering process and as well as incorporating the halal practices in their standard operating procedures as a self-compliance tool;

8. To create halal traceability system as a tool for communication, making information available along the supply chain;

9. To create awareness on the halal practices that do not only cover basic Syari'ah requirements, but also include other aspects such as food hygiene and safety; and

10. To establish a centre on new product development, food biotechnology, halal food ingredient, disease diagnostic as well as prevention and control on livestock.

\section{Conclusions}

a. It needs fully integrated in slaughtering facilities, fleet of transports and also processing for the food products value added activities. Other important aspects in the halal food supply chain are the halal market intelligence and also halal awareness among the players as well as customers. Market intelligence is important because it will be able to provide relevant information required by the industry in order to serve the customers more effectively and ef- ficiently. This is an important aspect in encouraging the industry players to be involved in halal food supply chain because it allows them to manage the operating costs and eventually creating acceptable profits for the companies.

b. Halal awareness programmes are one of the backbones of the whole chain because everybody needs to be able to understand the true meaning of halal food and how it can be produced. Without proper knowledge, players might unknowingly be involved in activities that can make halal food products to be non-halal

\section{Acknowledgement}

This paper was funded from MP3EI research scheme FY 2016/2017 by the Directorate of Research and Social Services, Ministry of Research, Technology and Higher Degree, Republic of Indonesia. Thanks to students of Prof. Indah Susilowati in Diponegoro Universityas, Muhammad Samsudin, Muhammad Ardiansyah and Abimanyu as enumerators. Great thanks to the anonymous reviewer who provides constructive inputs for this paper.

\section{References}

Abdul Manaf, B., Cheng, W. H., \& Nurwahida, F. (2013). The competitiveness of halal food industry in Malaysia: A SWOT - ICT analysis. Journal of Society and Space, 1(1), $1-9$.

Abdullah, A. N. Bin. (2006). Perception and Awarness Among Food Manufacturess And Marketers on Halal Food in The Klang Valley. Universiti Putra Malaysia.

Anggara, F. S. A. (2017). Development of Indonesia Halal Agroindustry Global Market in ASEAN: Strategic Assesment. Al Tijarah, 3(1), 82. https://doi.org/10.21111/tijarah. v3i1.940 
Avalaible online at http://journals.ums.ac.id, Permalink/DOI: 10.23917/jep.v19i1.5859

Jurnal Ekonomi Pembangunan: Kajian Masalah Ekonomi dan Pembangunan, 19 (1), 2018, 102-113

Bergeaud-Blackler, F. (2004). Social definitions of halal quality: the case of Maghrebi Muslims in France. (M. Harvey, Ed.), Qualities of food. Manchester: Manchester University Press. Retrieved from <Go to ISI >:// CABI:20053120395

Cutler, B. T. R. (2007). Food Safety Drives Growth in Kosher \& Halal Foods. Ifsqn. Florida.

Elasrag, H. (2016). Halal Industry: Key Challenges and Opportunities. Muenchen.

Creswell, J. (2014). Research Design Qualitative, Quantitative and Mixed Methods Approaches (4th ed.). Los Angeles: Sage Publication Ltd.

Melissa, W., \& Hassan, W. (2015). Halal Food in New Zealand Restaurants : An Exploratory Study Halal Food in New Zealand Restaurants : An. Int.Journal of Economics and Management, 3(October), 385-402.
Salman, F., \& Siddiqui, K. (2011). An exploratory study for measuring consumers awareness and perceptions towards halal food in Pakistan. Interdisciplinary Journal of Contemporary Research in Business, 3(2), 639-651. https://doi.org/10.7763/ IJSSH.2015.V5.413

Shikoh, R. U. (2015). Halal Business: The New Global Market Paradigm. Tokyo.

Wahab, A. R. (2004). Guidlines for the preparation of halal food and goods for the Muslim consumers. AmalMerge (M) Sdn. Bhd. Retrieved from http://www.sudairy.com/mer/ halal_guidelines_1.pdf

Wilson, J. A. J., \& Liu, J. (2010). Shaping the Halal into a brand? Journal of Islamic Marketing, 1(2), 107-123. https://doi. org/10.1108/17590831011055851 